\title{
PENGEMBANGAN GAME PANDORA BERBASIS PENEMUAN TER- BIMBING PADA SISTEM PERTIDAKSAMAAN LINEAR KUADRAT DUA VARIABEL
}

\author{
Liswanda Ayu Anggraeni ${ }^{1}$, Sri Hariyani2 ${ }^{2}$, Timbul Yuwono ${ }^{3}$ \\ 1,2,3 Fakultas Sains dan Teknologi, Universitas Kanjuruhan Malang \\ email koresponsdensi : liswandaayu@gmail.com
}

Diterima : (23-10-2020), Revisi: (03-12-2020), Diterbitkan : (24-12-2020)

\begin{abstract}
ABSTRAK
Pembelajaran konvensional mengakibatkan peserta didik kurang memahami konsep dari suatu materi. Dengan model dan media pembelajaran yang tepat, guru dapat membantu peserta didik untuk memahami konsep serta langkah pengerjaan dari suatu materi. Penelitian ini merupakan penelitian pengembangan media pembelajaran berbasis penemuan terbimbing. Tujuan penelitian ini adalah menghasilkan prosedur pengembangan game berbasis penemuan terbimbing serta menghasilkan game yang valid, praktis dan efektif. Model yang digunakan dalam penelitian ini yaitu model pengembangan Plomp (1997). Teknik pengumpulan data menggunakan teknik observasi dan angket. Hasil penilaian kevalidan oleh ahli materi dan ahli media yakni diperoleh rata-rata 3,41 sehingga masuk dalam kategori valid. Hasil penilaian kepraktisan oleh ahli praktisi dan angket respons peserta didik diperoleh rata-rata 3,46 sehingga masuk dalam kategori praktis. Persentase rata-rata nilai hasil tes peserta didik menunjukkan 100\% sehingga masuk dalam kategori efektif. Berdasarkan hasil penelitian, game pandora dapat digunakan sebagai media pembelajaran di sekolah karena sudah memenuhi kriteria valid, praktis dan efektif.

Kata kunci : Pandora; media pembelajaran; sistem pertidaksamaan linear kuadrat dua variabel.
\end{abstract}




\begin{abstract}
Conventional learning involves less understanding for students in the concept of material. Using the right model and media, the teacher may help the students to understand both the concept and the material's working steps. This study is a development study of media learning guided invention-based. The study aims to generate a guided invention-based game development procedure and generate a valid, simple, and effective game. This study is using the Plomp development model (1997). Data collection techniques used are observation and questionnaire. The validity assessment result by material and media expert is obtained on average 3,41, thus considered a valid category. The practicability assessment result by practitioner expert and learners questionnaire responsses are obtained on average 3.46 , therefore considered a simple category. The average learner's percentage value result showed $100 \%$, thus considered an effective category. According to the study result, the Pandora game can be used as media learning at school due to fulfilling the criteria such as validity, practicability, and effectiveness.
\end{abstract}

Key words: pandora, media learning, two-variable quadratic linear inequality system.

\title{
Pendahuluan
}

Jika guru melakukan pembelajaran yang inovatif dan menempatkan peserta didik sebagai pusat pembelajaran maka, peningkatan mutu pembelajaran dapat dicapai sehingga peserta didik dapat belajar bermakna (Guantara, dkk., 2014). Tetapi, pada kenyataannya guru masih belum bisa menjadikan peserta didik sebagai pusat pembelajaran. Hal ini sejalan dengan pendapat Saparwadi (2016) yang menyatakan bahwa dalam proses pembelajaran, guru masih menggunakan metode konvensional dimana peserta didik hanya mencatat dan merangkum penjelasan guru sehingga. Hal tersebut dapat menghambat proses kreativitas peserta didik. Akibatnya, peserta didik hanya dapat menghafal rumus dari materi yang diberikan sehingga peserta didik mengakui kurang paham karena tidak dibimbing untuk memahami konsep.

Dengan menerapkan suatu metode pembelajaran yang memberikan fasilitas kepada peserta didik, guru dapat untuk meningkatkan pemahaman konsep peserta didik dengan baik (Fajriah \& Sari, 2016). Salah satu metode pembelajaran yang berpusat pada pemahaman konsep peserta didik adalah metode penemuan. Penemuan yang dimaksud yaitu dimana peserta didik dapat mengembangkan pengetahuan mereka sendiri (Bruner, 1961). Terdapat dua cara untuk mengimple- 
mentasikan metode penemuan yaitu penemuan terbimbing (guided discovery) dan penemuan bebas (free discovery). Metode penemuan terbimbing merupakan metode yang dapat membimbing sekaligus dapat memberi arahan pada peserta didik. Menurut Annajmi (2016), pada pembelajaran metode penemuan terbimbing guru bertindak sebagai fasilitator yang mengarahkan peserta didik untuk menghubungkan pengetahuan yang dimiliki dengan pengetahuan yang dipelajari melalui pertanyaan-pertanyaan. Melalui suatu data, guru dapat mendorong peserta didik untuk mengamati, menyusun, memproses, serta mengorganisir secara mandiri agar dapat menemukan suatu konsep. Karim (2011), menunjukkan bahwa dengan metode penemuan terbimbing pemahaman konsep dan kemampuan berpikir kritis peserta didik lebih baik dari pembelajaran konvensional. Janssen (2014) menyatakan bahwa metode penemuan terbimbing merupakan metode yang dapat membantu guru untuk mengoptimalkan pembelajaran secara praktis.

Untuk memaksimalkan metode penemuan terbimbing, guru harus memiliki fasilitas yang baik untuk peserta didik salah satunya yaitu media pembelajaran. Selain itu, Astra, dkk (2015) menyatakan bahwa pembelajaran konvensional yang terjadi saat ini mengharuskan peserta didik untuk hadir dalam setiap proses pembelajaran dan tidak dapat mengakses materi kapan pun dan dimana pun sehingga dibutuhkan media pembelajaran yang dapat diakses peserta didik dimana pun dan kapan pun. Hartanti (2020) menyatakan bahwa media pembelajaran bermanfaat untuk menumbuhkan rasa antusias peserta didik serta menjadi fasilitas dalam kegiatan pembelajaran. Seiring perkembangan teknologi, banyak peserta didik yang aktif menggunakan perangkat mobile salah satunya yaitu untuk bermain game.

Hasil dari observasi saat melaksanakan di SMK An Nur Bululawang, masih banyak peserta didik yang mengisi waktu libur dengan bermain game. Kurniawan (2017) menyatakan bahwa salah satu penyebab remaja malas belajar yaitu game online. Jika peserta didik lebih banyak menggunakan waktu untuk bermain game online maka waktu belajar menjadi lebih sedikit dan hal ini yang menjadi ketakutan yang akhirnya menjadi bumerang bagi asa depan peserta didik (Irmawati \& Suhaeb, 2017). Untuk menyelaraskan kedua hal tersebut, maka diciptakan game yang berisi pembelajaran.

Sari, dkk (2014) menyebutkan bahwa game edukasi dapat menjadi media pembelajaran yang menantang serta menyenangkan bagi peserta didik. Selain itu, 
menurut Sari, dkk (2017) mengatakan bahwa game edukasi dapat memotivasi untuk mempertahankan dan meningkatkan minat belajar peserta didik. Vos, dkk. (2011) menyatakan bahwa terdapat perbedaan signifikan antara peserta didik yang belajar dengan menggunakan game pembelajaran dan tidak menggunakannya. Peserta didik yang belajar menggunakan bantuan game pembelajaran dapat lebih mendalam untuk memahami materi pembelajaran. Oleh karena itu, game dapat menjadi media pembelajaran yang baik untuk guru membimbing peserta didik melakukan proses pembelajaran dengan metode penemuan terbimbing. Dari hasil observasi, peserta didik masih belum memahami konsep dan langkah pengerjaan materi Sistem Pertidaksamaan Linear Kuadrat Dua Variabel (SPtLKDV) untuk menemukan himpunan penyelesaian sehingga peneliti mengambil materi tersebut sebagai bahan ajar.

Penelitian tentang pengembangan game edukasi pernah dilakukan sebelumnya. Penelitian yang dilakukan oleh Romadhona (2018) menunjukkan bahwa game edukasi dapat menarik minat belajar dan meningkatkan hasil belajar peserta didik. Namun, masih terdapat kekurangan yaitu peneliti hanya memberikan materi secara singkat dan latihan soal pada game. Penelitian lain mengenai pengembangan game edukasi juga pernah dilakukan oleh Pramuditya, Noto, \& Purwono (2017) menunjukkan bahwa game merupakan salah satu media pembelajaran yang praktis untuk kegiatan pembelajaran karena adanya proses interaksi antara game dan pengguna sehingga peserta didik mudah untuk memahami materi yang disajikan tetapi, game tersebut masih belum dapat membuat peserta didik membangun pengetahuannya sendiri.

Penelitian ini berbeda dengan penelitian sebelumnya, penelitian ini membahas game berbasis penemuan terbimbing dimana peserta didik dapat membangun pengetahuannya sendiri dan memahami konsep suatu masalah matematika. Penelitian ini merupakan jenis penelitian pengembangan yang bertujuan untuk menghasilkan produk serta mengetahui kualitas produk yang dikembangkan. Penelitian ini penting dilakukan untuk membantu peserta didik SMK An Nur Bululawang memahami langkah-langkah pengerjaan soal pada materi sistem pertidaksamaan linear kuadrat dua variabel.

\section{Metode Penelitian}

Penelitian ini merupakan jenis penelitian pengembangan. Produk yang dihasilkan 
dalam penelitian berupa game pandora berbasis penemuan terbimbing yang berisi materi sistem pertidaksamaan linear kuadrat dua variabel. Model pengembangan yang digunakan dalam pengembangan media game ini adalah model pengembangan Plomp (1997). Rochmad (2012) memandang bahwa model pengembangan Plomp lebih fleksibel dan luwes dibandingkan model pengembangan lainnya karena setiap langkah kegiatan pengembangan dapat disesuaikan dengan karakteristik penelitian.

Langkah-langkah model pengembangan Plomp terbagi menjadi lima tahapan, yaitu (1) preliminary investigation (fase investigasi awal) merupakan langkah awal untuk peneliti melakukan analisis dasar permsalahan, (2) design (fase perancangan) berisi pembuatan rancangan dari produk, (3) realization (fase realisasi) berisi penuangan rancangan ke dalam produk dan menghasilkan prototype 1, (4) test, evaluation, and revision (fase tes, evaluasi, revisi) berisi kegiatan uji coba produk, evaluasi, serta revisi sehingga menghasilkan prototype akhir, dan (5) implementation (fase implementasi) berisi kegiatan mengimplementasikan produk yang sudah teruji. Adapun langkah-langkah penelitian menggunakan model Plomp ditunjukkan pada gambar 1 berikut. 


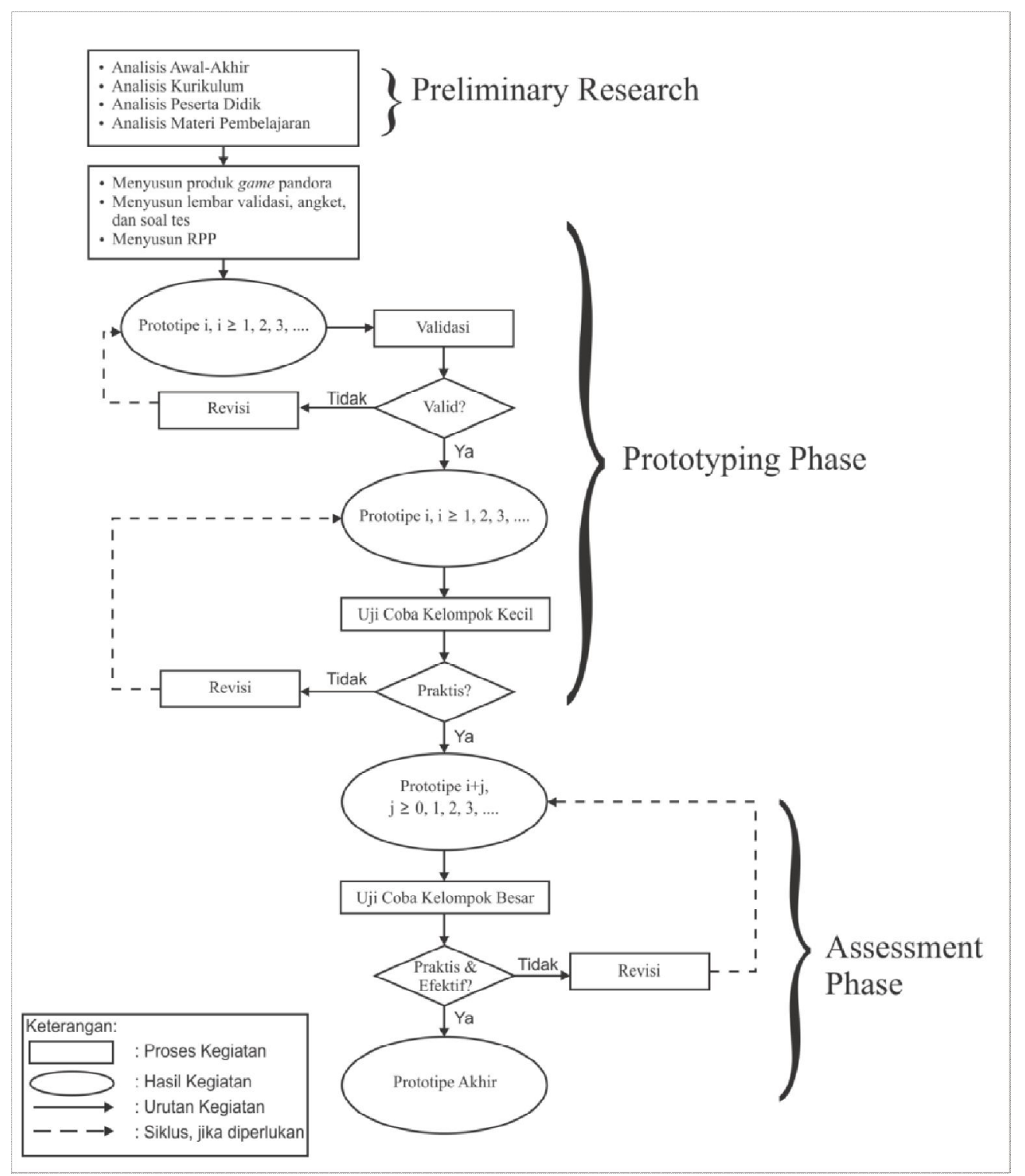

Gambar 1. Langkah-Langkah Model Pengembangan Plomp

Penelitian ini dilakukan pada semester genap 2019/2020 di SMK An Nur Bululawang dengan subjek peserta didik kelas X. Uji coba penelitian dilakukan sebanyak dua kali yaitu uji coba lapangan terbatas yang dilakukan oleh 6 peserta dan uji coba lapangan luas yang dilakukan oleh 18 peserta.

Instrumen pengumpulan data yang digunakan terbagi menjadi 3, yaitu lembar validasi untuk uji kevalidan media, lembar kepraktisan dan angket respons peserta didik untuk uji kepraktisan media, serta tes hasil belajar peserta didik untuk uji kelayakan media. Teknik analisis kevalidan media sebagai berikut. 


$$
V a=\frac{\sum_{i=1}^{n} I_{i}}{m}
$$

Keterangan:

$\sum_{i=1}^{n} I_{i} \quad$ : jumlah rata-rata nilai hasil validasi pada indikator ke-i

$m \quad$ : banyak indikator

Untuk menghitung rata-rata nilai hasil validasi dari semua validator untuk setiap indikator $\left(\mathrm{I}_{\mathrm{i}}\right)$ dengan rumus:

$$
I_{i}=\frac{\sum_{j=1}^{n} V_{j, i}}{n}
$$

Keterangan:

$\sum_{j=1}^{n} V_{j, i}$ : jumlah nilai validator ke-j untuk indikator ke-i

$n \quad$ : banyaknya validator

Untuk menentukan kevalidan dapat dilihat dari kriteria kevalidan media pembelajaran yang disajikan pada tabel 1 .

Tabel 1. Kriteria Kevalidan Media Pembelajaran

\begin{tabular}{ccc}
\hline Nilai & Kriteria & Keterangan \\
\hline $\mathrm{Va}=4.00$ & Sangat Valid & Tidak Ada Revisi \\
$3.25 \leq \mathrm{Va}<4.00$ & Valid & Tidak Ada Revisi \\
$2.50 \leq \mathrm{Va}<3.25$ & Cukup Valid & Revisi Sebagian \\
$1.75 \leq \mathrm{Va}<2.50$ & Kurang Valid & Revisi Sebagian \\
$1.00 \leq \mathrm{Va}<1.75$ & Tidak Valid & Revisi Total \\
\hline
\end{tabular}

Nasution (2016)

Teknik analisis uji kepraktisan media sebagai berikut.

$$
P=\frac{\sum_{i=1}^{n} I_{i}}{m}
$$

Keterangan:

$\sum_{i=1}^{n} I_{i} \quad$ : jumlah rata-rata nilai angket respons peserta didik pada indikator ke-i

$m \quad$ : banyaknya indikator

Untuk menghitung rata-rata hasil uji kepraktisan media untuk setiap indikator $\left(\mathrm{I}_{\mathrm{i}}\right)$ dengan rumus:

$$
I_{i}=\frac{\sum_{j=1}^{n} P_{j, i}}{n}
$$

Keterangan:

$\sum_{j=1}^{n} P_{j, i}$ : jumlah nilai angket respons peserta didik ke-j untuk indikator ke-i

$n \quad$ : banyaknya peserta didik 
Untuk menentukan kepraktisan dapat dilihat dari kriteria kepraktisan media pembelajaran yang disajikan pada tabel 2 .

Tabel 2. Kriteria Kepraktisan dan Angket Respons Peserta Didik Media Pembelajaran

\begin{tabular}{ccc}
\hline Nilai & Kriteria & Keterangan \\
\hline $\mathrm{P}=4.00$ & Sangat Praktis & Tidak Ada Revisi \\
$3.25 \leq \mathrm{P}<4.00$ & Praktis & Tidak Ada Revisi \\
$2.50 \leq \mathrm{P}<3.25$ & Cukup Praktis & Revisi Sebagian \\
$1.75 \leq \mathrm{P}<2.50$ & Kurang Praktis & Revisi Sebagian \\
$1.00 \leq \mathrm{P}<1.75$ & Tidak Praktis & Revisi Total \\
\hline
\end{tabular}

Nasution (2016)

Teknik menghitung persentase keefektifan (E) dilakukan setelah mendapat nilai hasil tes belajar setiap peserta didik menggunakan rumus:

$$
E=\frac{x}{n} \times 100 \%
$$

Keterangan:

$x \quad$ : banyaknya peserta didik yang mendapat nilai diatas 75

$n \quad$ : banyaknya peserta didik uji coba

Apabila persentase keefektifan memperoleh hasil minimal 80\% peserta didik yang mendapat nilai diatas KKM, maka media game pandora dikatakan efektif. Namun, apabila persentase keefektifan memperoleh hasil kurang dari 80\% peserta didik yang mendapat nilai di atas KKM maka media game pandora belum dapat dikatakan efektif.

\section{Hasil dan Pembahasan}

Tahap awal pengembangan game pandora yaitu preliminary investigation (fase investigasi awal). Kegiatan pada fase ini meliputi analisis awal, analisis kurikulum dan analisis peserta didik. Hasil yang diperoleh yaitu, (1) peserta didik sulit untuk memahami urutan langkah-langkah dalam pengerjaan sistem pertidaksamaan linear kuadrat dua variabel sehingga peserta didik menjadi malas untuk belajar, (2) kurikulum yang digunakan yaitu kurikulum 2013 revisi 2017 berbasis teaching factory, (3) peserta didik merupakan santri dari Pondok Pesantren An Nur sehingga di luar jam pembelajaran formal, peserta didik mengikuti pembelajaran di pondok pesantren. Oleh karena itu, peserta didik hanya dapat melakukan pembelajaran mandiri pada waktu yang kosong.

Tahap selanjutnya yaitu design (fase perancangan) adalah kegiatan menyusun 
rancangan pembuatan produk. Game pandora merupakan suatu media pembelajaran yang disajikan dalam bentuk aplikasi pada mobile maupun personal computer. Untuk pembuatan dibutuhkan storyboard sebagai gambaran game pandora yang berisi gambar, scene, waktu dan navigasi. Selain itu, dalam pembuatan game pandora juga dirancang skenario agar alur cerita yang ada pada game menjadi lebih terstruktur.

Realization (fase realisasi) bertujuan untuk menghasilkan suatu produk. Rancangan yang telah dibuat akan direalisasikan pada tahap ini sebagai prototype 1. Game pandora dibuat dengan menggunakan software RPG Maker MV. Berikut adalah gambaran game pandora.
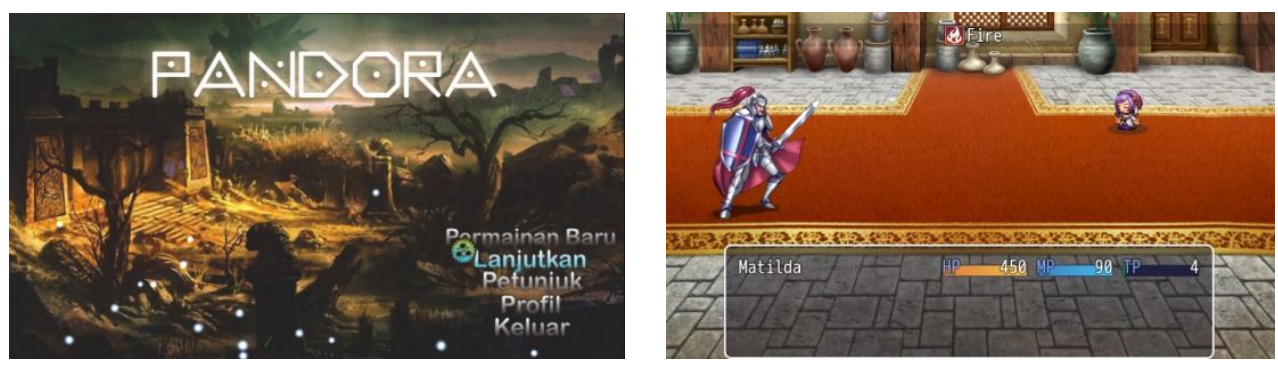

Gambar 2. Tampilan Halaman Utama (Kiri) dan Tampilan Battle (Kanan)
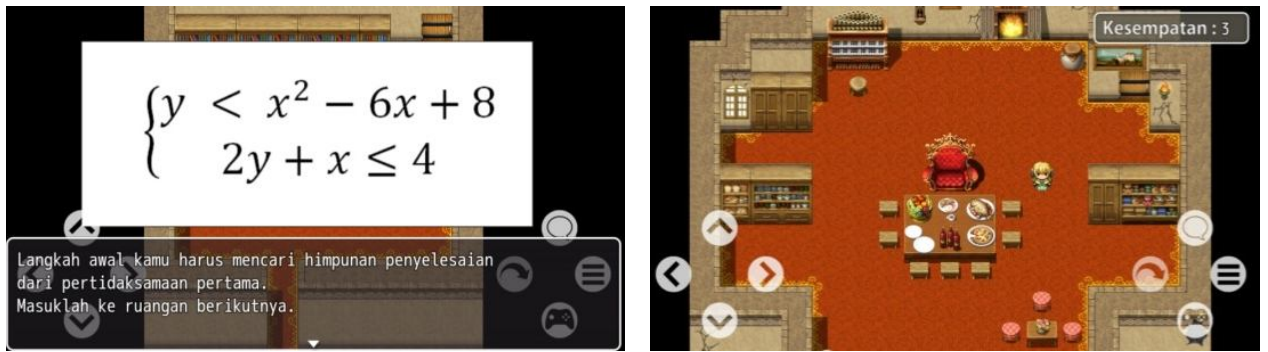

Gambar 4. Tampilan Soal (Kiri) dan Tampilan Ruang (Kanan)

Setelah produk selesai dibuat, tahap selanjutnya yaitu test, evaluation, and revision (fase tes, evaluasi, dan revisi). Pada fase ini dilakukan uji validitas, uji kepraktisan, dan uji lapangan terbatas media game pandora. Hasil uji validitas dapat dilihat pada tabel 3.

Tabel 3. Hasil Validasi Game Pandora

\begin{tabular}{ccc}
\hline Validator & Hasil Validasi & Kriteria \\
\hline Ahli Materi & 3.54 & Valid \\
Ahli Media & 3.28 & Valid \\
Rata-Rata & 3.41 & Valid \\
\hline
\end{tabular}


Berdasarkan penilaian ahli materi dan ahli media tersebut game pandora memperoleh kriteria valid sehingga dapat digunakan untuk uji coba. Hal ini sesuai dengan pernyataan Suryadi (2017) bahwa game dapat memberikan pengaruh terhadap motivasi belajar serta meningkatkan pemahaman peserta didik. Namun, terdapat komentar dan saran. Ahli materi mengatakan bahwa media game pandora sudah baik akan tetapi interaksi guru dan peserta didik dalam media masih kurang, jika diperlukan ada perbaikan sehingga terdapat aktivitas penemuan terbimbing pada media game pandora. Namun, peneliti memiliki keterbatasan dalam pembuatan media, sehingga saran tersebut dapat digunakan sebagai pengembangan untuk penelitian selanjutnya. Ahli media mengatakan dalam media pandora masih terdapat kesalahan pengetikan pada instruksi maupun soal. Komentar dari ahli media telah direvisi oleh peneliti.

Setelah media dikatakan valid, selanjutnya diuji kepraktisan oleh ahli praktisi dan angket respons peserta didik. Revita (2019) menyatakan bahwa kepraktisan media pembelajaran dapat dilihat dari beberapa aspek yaitu kemudahan penggunaan media pembelajaran, keterbacaan dan penyajian media pembelajaran, waktu yang dibutuhkan dalam media yang dikembangkan dalam kegiatan pembelajaran.. Hasil uji kepraktisan dapat dilihat pada tabel 4.

Tabel 4. Hasil Uji Kepraktisan Game Pandora

\begin{tabular}{ccc}
\hline Pengguna & Hasil Validasi & Kriteria \\
\hline Ahli Praktisi & 3,62 & Praktis \\
Angket Respons & 3,30 & Praktis \\
Peserta Didik & 3,46 & Praktis \\
Rata-Rata & &
\end{tabular}

Berdasarkan penilaian ahli praktisi dan angket respons peserta didik tersebut game pandora memperoleh kriteria praktis. Namun, masih terdapat beberapa komentar yang sama yaitu kapasitas game pandora yang terlalu besar sehingga menyebabkan kinerja game menjadi lambat pada mobile maupun personal computer yang memiliki kapasitas RAM sedikit. Namun, peneliti memiliki keterbatasan dalam pembuatan media, sehingga komentar tersebut dapat digunakan sebagai pengembangan untuk penelitian selanjutnya. Game pandora yang sudah dinyatakan valid dan praktis, selanjutnya akan dilakukan uji coba lapangan terbatas. Hasil tes peserta didik lapangan terbatas dapat dilihat pada tabel 5. 
Tabel 5. Hasil Tes Peserta Didik Uji Lapangan Terbatas

\begin{tabular}{lcc}
\hline No & Nama & Nilai \\
\hline 1. & MB & 100 \\
2. & IS & 96,07 \\
3. & FTD & 100 \\
4. & RS & 100 \\
5. & DM & 100 \\
6. & LDA & 98,03 \\
\hline
\end{tabular}

Berdasarkan tabel 5 diketahui bahwa persentase rata-rata nilai hasil tes peserta didik saat uji coba lapangan terbatas adalah 100\%. Karena hasil yang didapatkan sudah 100\% maka peneliti tidak melakukan revisi produk setelah melakukan uji lapangan terbatas, sehingga game pandora dapat dilakukan untuk uji coba lapangan luas. Hasil tes peserta didik lapangan terbatas dapat dilihat pada tabel 6 .

Tabel 6. Hasil Tes Peserta Didik Uji Lapangan Luas

\begin{tabular}{ccc|ccc}
\hline No & Nama & Nilai & No & Nama & Nilai \\
\hline 1. & DM & 98,03 & 10. & DFP & 98,03 \\
2. & NAW & 100 & 11. & RCP & 100 \\
3. & AP & 98,03 & 12. & AN & 86,27 \\
4. & MWY & 94,11 & 13. & MRA & 96,07 \\
5. & SS & 100 & 14. & MAZ & 98,03 \\
6. & NHK & 100 & 15. & NL & 100 \\
7. & RNF & 100 & 16. & NWS & 100 \\
8. & DPC & 98,03 & 17. & MNF & 100 \\
9. & RR & 100 & 18. & MRS & 98,03 \\
\hline
\end{tabular}

Berdasarkan tabel 6 diketahui bahwa persentase rata-rata nilai hasil tes peserta didik saat uji coba lapangan luas adalah 100\% sehingga game pandora dapat dikatakan efektif untuk pembelajaran sistem pertidaksamaan linear kuadrat dua variabel. Hal ini sesuai dengan pernyataan Rohwati (2012) yang mengatakan bahwa penggunaan game edukasi dapat meningkatkan hasil belajar peserta didik. Giannakos (2013) menyatakan bahwa game edukasi dapat meningkatkan hasil belajar peserta didik karena didukung faktor perasaan senang saat belajar sehingga tidak menjadi beban oleh peserta didik. Peserta didik merasa bahwa kapasitas game yang terlalu besar sehingga menyebabkan kinerja game menjadi lambat pada mobile maupun pesonal computer yang memiliki kapasitas RAM sedikit.

\section{Kesimpulan}

Berdasarkan hasil penelitian yang telah dilakukan di SMK An Nur Bululawang diperoleh hasil game pandora yang dikembangkan memperoleh skor rata-rata 3.41 
maka, game pandora dapat dikategorikan dalam kriteria valid. Berdasar penilaian tersebut, maka media dapat diimplementasikan. Game pandora yang dikembangkan memperoleh skor rata-rata 3.46 maka, game pandora dapat dikategorikan dalam kriteria praktis. Uji keefektifan pada game pandora dilakukan dua tahap yaitu, uji lapangan terbatas yang memiliki hasil 100\% peserta didik memiliki nilai diatas KKM dan uji lapangan luas yang memiliki hasil 100\% peserta didik memiliki nilai diatas KKM maka, game pandora dapat dikatakan efektif. Oleh karena itu, game pandora dapat digunakan untuk menarik minat belajar peserta didik serta membantu peserta didik memahami langkah pengerjaan soal pertidaksamaan liner kuadrat dua variabel. Saran untuk peneliti selanjutnya adalah peneliti diharapkan dapat menciptakan interaksi guru dan peserta didik dalam aktivitas penemuan terbimbing dalam game serta memperkecil kapasitas aplikasi game.

\section{Ucapan Terima kasih}

Peneliti mengucapkan terima kasih kepada Jumat Hadi S M, S.Si selaku kepala SMK An Nur Bululawang dan M. Bahtiar Arif, M.Pd selaku guru matematika SMK An Nur Bululawang yang telah memberi dukungan dalam proses penelitian serta, berbagai pihak yang telah membantu dalam penelitian ini.

\section{Daftar Pustaka}

Astra, I. M., Nasbey, H., \& Nugraha, A. (2015). Development of an android application in the form of a simulation lab as learning media for senior high school students. Eurasia Journal of Mathematics, Science and Technology Education, Vol. 11, No. 5, 1081-1088.

Annajmi, A. (2016). Peningkatan Kemampuan Pemahaman Konsep Matematika Siswa SMP Melalui Metode Penemuan Terbimbing Berbantuan Software Geogebra. Journal of Mathematics Education and Science, Vol. 2, No. 1, 1-10.

Bruner, J. S. (1961). The act of discovery. Harvard Educational Review, 31, 21-32.

Fajriah, N \& Desnalia S. (2016). Meningkatkan Pemahaman Konsep Matematis Siswa Pada Materi SPLDV Melalui Model Pembelajaran Kooperatif Tipe Think-Pair-Share di Kelas VIII SMP. EDU-MAT Jurnal Pendidikan Matematika, Vol 4, No.1, 68-75.

Giannakos, M. N. (2013). Enjoy and learn with educational games: Examining factors affecting learning performance. Computers \& Education, Vol. 68, 429-439.

Gunantara, G, Suarjana I.M, \& Putu N.R. (2014). Penerapan Model Pembelajaran 
Problem Based Learning Untuk Meningkatkan Kemampuan Pemecahan Masalah Matematika Siswa Kelas V. Jurnal Mimbar PGSD Universitas Pendidikan Ganesha Jurusan PGSD, Vol. 2, No. 1.

Hartanti, F.D. Sri H, \& Trija F. (2020). Pengembangan Media Pembelajaran Matematika Sigeru Buku Pop-Up Berbasis Etnomatematika Materi Kubus dan Balok. Jurnal Pendidikan dan Pembelajaran Matematika, Vol. 6, No. 1, 22-30.

Irmawati, I \& Firdaus W.S. (2017). Dampak Bermain Game Online pada Hasil Belajar Siswa di SMAN 12 Makassar. Jurnal Sosial Pendidikan Sosiologi-FIS UNM, Vol. 4, No. 2, 95-99.

Janssen, F. J., Westbroek, H. B., \& van Driel, J. H. (2014). How to make guided discovery learning practical for student teachers. Instructional Science, Vol. 42, No. 1, 67-90.

Karim, A. (2011). Penerapan metode penemuan terbimbing dalam pembelajaran matematika untuk meningkatkan pemahaman konsep dan kemampuan berpikir kritis siswa sekolah dasar. Jurnal pendidikan, Vol. 1, No. 1, 21-32.

Kurniawan, E.D. (2017). Pengaruh Intensitas Bermain Game Online Terhadap Perilaku Prokrastinasi Akademik Pada Mahasiswa Bimbingan dan Konseling Universitas PGRI Yogyakarta. Jurnal Konseling GUSJIGANG, Vol. 3, No. 1, 97-103.

Nasution, S.H, Lathiful A, Sudirman \& Susiswo. (2015). Pengembangan Media Pembelajaran untuk Mendukung Kemampuan Penalaran Spasial Peserta didik Pada Topik Dimensi Tiga Kelas X. Jurnal Keguruan dan Ilmu Pendidikan,Vol 4, No. 2, 903 - 913.

Plomp, T. (1997). Educational Design: Introduction. From Tjeerd Plomp (eds). Educational \& Training System Design: Introduction. Design of Education and Training. U. of T. Faculty of Educational Science and Technology (Ed.)(1st ed., pp. 1-87). Lemma. Netherland: University of Twente.

Pramuditya, SA, M.. Subali N, \& Dede S. (2017). Game Edukasi RPG Matematika. EduMa, Vol. 6, No. 1, 77-84.

Revita, R. (2019). Uji Kepraktisan Perangkat Pembelajaran Matematika Berbasis Penemuan Terbimbing untuk SMP. Juring (Journal for Research in Mathematics Learning), Vol. 2 , No. 2, 148-154.

Rohwati, M. (2012). Penggunaan Education Game Untuk Meningkatkan Hasil Belajar IPA Biologi Konsep Klasifikasi Makhluk Hidup. Jurnal Pendidikan IPA Indonesia, Vol. 1, No. 1, 75-81. 
Romadhona, FT. (2018). Pengembangan Edugame Berbasis Role Play Game (RPG) pada Mata Pelajaran Simulasi Digital Kelas X Tav di SMKN 3 Surabaya. Jurnal Pendidikan Teknik Elektro,Vol. 7, No. 2, 101-107.

Sari, K.W, Sulistyo S, \& Budi H. (2014). Pengembangan Game Edukasi Kimia Berbasis Role Playing Game (RPG) Pada Materi Struktur Atom Sebagai Media Pembelajaran Mandiri untuk Siswa Kelas X SMA di Kabupaten Purworejo. Jurnal Pendidikan Kimia (JPK), Vol. 3, No. 2, 96-104.

Sari, S., Anjani, R., Farida, I., \& Ramdhani, M. A. (2017). Using android-based educational game for learning colloid material. Journal of Physics: Conference Series, Vol. 895, No. 1, p. 012012.

Saparwadi, L. (2016). Efektivitas Metode Pembelajaran Drill dengan Pendekatan Peer Teaching Ditinjau dari Minat dan Prestasi Belajar Matematika Siswa. Jurnal Dikdatik Matematika, Vol. 3, No. 1, 39-46.

Suryadi, A. (2017). Perancangan Aplikasi Game Edukasi Menggunakan Model Waterfall.Jurnal PETIK, Vol 3, No. 1, 8-13.

Vos, N., Van Der Meijden, H., \& Denessen, E. (2011). Effects of constructing versus playing an educational game on student motivation and deep learning strategy use. Computers \& Education, Vol. 56, No. 1, 127-137. 